\title{
Review 2: Primary graft dysfunction after lung transplant-pathophysiology, clinical considerations and therapeutic targets
}

\author{
${\text { Zhaosheng } \operatorname{Jin}^{1} \cdot \text { Ka Chun Suen }}^{1} \cdot$ Zhiping Wang $^{2} \cdot$ Daqing Ma $^{1}$
}

Received: 20 August 2019 / Accepted: 4 July 2020 / Published online: 20 July 2020

(c) The Author(s) 2020

\begin{abstract}
Primary graft dysfunction (PGD) is one of the most common complications in the early postoperative period and is the most common cause of death in the first postoperative month. The underlying pathophysiology is thought to be the ischaemia-reperfusion injury that occurs during the storage and reperfusion of the lung engraftment; this triggers a cascade of pathological changes, which result in pulmonary vascular dysfunction and loss of the normal alveolar architecture. There are a number of surgical and anaesthetic factors which may be related to the development of PGD. To date, although treatment options for PGD are limited, there are several promising experimental therapeutic targets. In this review, we will discuss the pathophysiology, clinical management and potential therapeutic targets of PGD.
\end{abstract}

Keywords Lung transplantation · Primary graft dysfunction · Reperfusion injury · Therapeutics

\section{Introduction}

Since the first successful lung transplant in 1981, there have been tremendous advances in technology, surgical and anaesthetic techniques, as well as postoperative care of lung transplant patients [1]. The morbidity and mortality rates are considerably lower compared to a decade ago, and it is estimated that more than 4000 lung transplants are now carried out each year worldwide $[2,3]$. However, the early postoperative period remains a perilous time for the patients. It is estimated that approximately $7 \%$ of lung transplant patients dies within the first month after the operation, and more will suffer complications [2].

Primary graft dysfunction (PGD) is one of the most frequent complications in the early postoperative period. It occurs in approximately $10 \%$ of the recipients, and is associated with $42 \%$ mortality in the month after transplant,

Daqing Ma

d.ma@imperial.ac.uk

1 Anaesthetics, Pain Medicine and Intensive Care, Department of Surgery and Cancer, Faculty of Medicine, Imperial College London, Chelsea and Westminster Hospital, London SW10 9NH, UK

2 Department of Anesthesiology, Affiliated Hospital of Xuzhou Medical University, Xuzhou, Jiangsu, China sevenfold increase compared to patients without PGD [4]. In our previous review, we discussed the pre-transplantation issues with donor and graft selection, graft harvesting and storage. In this review, we will discuss the pathophysiology of ischaemia reperfusion injury (IRI) and PGD.

\section{Primary graft dysfunction}

PGD is the most common cause of death in the first 30 days after lung transplant [2]. It occurs usually within the first 3 days after lung transplant as demonstrated by hypoxemia secondary to impaired gas exchange and is associated with non-cardiogenic pulmonary infiltrates on chest radiograph [5]. It can be classified according to the Internal Society of Heart and Lung Transplant (ISHLT) grading system based on the arterial $\mathrm{O}_{2}$ partial pressure to fraction of inspired $\mathrm{O}_{2}$ $\left(\mathrm{PaO}_{2} / \mathrm{FiO}_{2}\right)$ ratio and the presence of chest radiograph findings. High-grade graft dysfunction is defined as the presence of both high $\mathrm{PaO}_{2} / \mathrm{FiO}_{2}$ ratio and radiological pulmonary infiltrate which is associated with significantly worse prognosis [6]. It has been found that more severe PGD as defined by the ISHLT grading system is associated with significantly worse prognosis [7]. In most lung transplant cases, the graft vasculature is flushed with preservative solution which is later kept in cold storage for the transfer process. It has been 
noted in animal studies that even without the transplant surgery, iatrogenic lung ischaemia and subsequent reperfusion results in respiratory and haemodynamic changes similar to that of PGD, demonstrating hypoxia, pulmonary oedema and reduced lung compliance [8-10]. It is, therefore, thought that IRI is likely to play a significant role in the development of PGD [11].

\section{Ischaemia reperfusion injury}

\section{Energy depletion}

As discussed in our previous review, ischaemia can very rapidly lead to a cascade of pathological changes in the cells. High-energy phosphate becomes depleted, which impairs a wide range of vital cellular functions. The lack of $\mathrm{Na}^{+} /$ $\mathrm{K}^{+}$ATPase action results in rapid loss of electrochemical gradients, while influx of sodium causes cell swelling. Dysregulated calcium homeostasis results in calcium accumulation in the cytosol which results in aberrant activation of various signalling systems such as membrane phospholipase and phosphokinases [12,13]. Ultimately, damage caused by ischaemia results in cell death and the release of damageassociated molecular patterns molecules such as HMGB-1 and HSP-60 [14, 15]. These molecules can bind to receptors such as Toll-like receptors and RAGE, and results in activation of MAPK and nuclear factor kappa-light-chainenhancer of activated B cells (NF-kB). This eventually leads to the upregulation in cytokine production, which not only activates the alveolar resident macrophages, but also serves as chemo-attractants and activators to circulating immune cells upon reperfusion [16].

During ischaemia, metabolism of ATP results in the accumulation of hypoxanthine, which upon reperfusion induces oxidative stress [11]. In addition, it is thought that lack of shear stress on the vascular endothelium results in upregulated expression of nicotinamide adenine dinucleotide phosphate oxidase (NADPH oxidase) [17]. Subsequently during reperfusion, the upregulated activities of NADPH oxidase results in a surge of reactive oxygen species (ROS) generation.

It has also been demonstrated that ischaemia can result in significant vascular dysfunction. Studies have shown that cold ischaemia which occurs during storage can results in significant vascular endothelial structural changes [18], increasing the vascular permeability [19] while impairing pulmonary vasodilatation [20]. The vascular dysfunction further worsens the pathological changes upon reperfusion.

What is unique in lung graft, however, is its gas exchange surface and ability to maintain oxygenation in ischemic condition. In animal models, preservation of lung graft inflated with $21 \%$ oxygen maintained its ATP and lactate level for more than 60 min during warm ischaemia; this is further augmented in grafts inflated with $100 \%$ oxygen, which maintained ATP production for almost 5 hours [21]. As such, it is recommended that lung grafts should be stored inflated or ventilated [6].

\section{Oxidative and nitrosative stress}

IRI is often characterised by rapid accumulation of ROS soon after reperfusion, with increased activities of ROSgenerating enzymes such as NADPH oxidase, xanthine oxidase and myeloperoxidase $[8,17,22,23]$. Reduction in anti-oxidative capacity $[15,24]$ and the occurrence of oxidative stress [24-27] are also observed. NADPH oxidase activity seems to play a significant role in the pathophysiology of IRI, as NADPH oxidase knockout animal demonstrates significantly blunted oxidative stress and inflammatory response to IRI. The lung grafts also displayed improved compliance, reduced pulmonary hypertension and oedema. Similar findings were also seen with NADPH oxidase inhibition [15, 22]. It is thought that NADPH oxidase activity may also enhance the release of chemokines such as (C-X-C motif) ligand 1 (CXCL1), CXCL2, (C-C motif) ligand 2 (CCL 2) and CCL 5 responsible for further recruiting immune cells such as neutrophils to the site of injury $[15,22]$. The recruitment of neutrophil leads to a number of detrimental effects on the lung tissue, including further generation of ROS [28].

Another important source of reactive oxygen species is the activity of xanthine oxidase. Xanthine oxidase is an oxidoreductase which catalyses the reaction of hypoxanthine to xanthine, then to uric acid. Both steps generate hydrogen peroxide. As mentioned previously, hypoxia leads to the accumulation of hypoxanthine from the breakdown of ATP [11]. Studies in the past have also suggested that xanthine oxidase conversion from its precursor enzyme xanthine dehydrogenase is augmented by hypoxia and by neutrophil activity [29-31]. The upregulated xanthine oxidase activity, as well as an abundance of substrate leads to the excessive production of ROS. Indeed, it has been demonstrated that xanthine oxidase inhibition in animal models of IRI can significantly reduce the extent of the endothelial dysfunction [32].

In addition, oxidative stress generated by NADPH oxidase may also have an impact on the nitric oxide synthase (NOS) function. Oxidation of the NOS co-factor tetrahydrobiopterin uncouples NOS function, and causes it to generate ROS instead of nitric oxide, which further adds to the oxidative burden [33, 34]. In the presence of excessive ROS, nitric oxide may also be converted to peroxynitrite, a reactive nitrogen species which could cause oxidation and nitration injury [35]. 


\section{Inflammatory response}

IRI is associated with a cascade of proinflammatory changes, including the upregulation of cytokines such as tumour necrosis factor- $\alpha$ (TNF- $\alpha$ ), Interleukin-1 $\beta$ (IL-1 $\beta$ ), IL-6; chemokines such as CCL1, CCL5, CXCL2 (IL-8); as well as immune cell adhesion molecules such as integrin, intercellular adhesion molecule 1 (ICAM 1) and vascular cell adhesion protein (VCAM) [36-38]. It is thought that TNF- $\alpha$ upregulates NF- $\kappa B$ by inhibiting I $\kappa B$, which further upregulates TNF- $\alpha$ production and other inflammatory mediators as mentioned above $[15,36,38,39]$. This promotes the chemotaxis of inflammatory cells such as neutrophils and natural killer cells.

Indeed, IRI is characterised by neutrophil infiltration and neutrophil activity, and inhibiting neutrophil function reduces the extent of ischaemia reperfusion related damage $[23,24,38,40]$, while IL-17, produced by natural killer T cell, is another potent neutrophil chemoattractant [41].

\section{Outcome of injury: vascular dysfunction and loss of alveolar architecture}

Pre-clinical studies showed that lung IRI is characteristically associated with pulmonary hypertension and increase in the lung water content. Cold storage could impair the function of both the endothelial barrier and the vascular smooth muscles [18-20]. In addition, both the recruited neutrophil and ROS generation during the reperfusion has also been shown to cause increase in permeability [22, 42-44]. The injury has also been associated with impaired vascular smooth muscle relaxation, leading to pulmonary hypertension $[45,46]$. It has been suggested that this is likely mediated by HIF- $1 \alpha$, iNOS and ATP dependent potassium channels [47, 48].

The combination of cell death, inflammatory changes and pulmonary vascular dysfunction leads to widespread changes to the microscopic architecture of the alveolar space, with interstitial oedema, neutrophil infiltration, hyaline membrane formation and intra-alveolar haemorrhages [49-51]. Not surprisingly, this impairs both the alveolar gas exchange as well as the ventilation mechanics.

\section{Pre-transplant risk factors of PGD}

Clinically, both donor and recipient factors could impact on the occurrence of PGD. Donor factors include age and history of smoking, gender and pre-existing illness [52-55]. Recipient factors include BMI, gender, pre-existing lung pathologies such as sarcoidosis, pulmonary fibrosis and pulmonary hypertension $[52,56,57]$. Prolonged ischaemic time is also associated with significantly higher risk of PGD [52].

It is estimated that PGD accounts for almost 1 in 4 posttransplant deaths in the first month $[55,58]$. In recent years, extensive research has been done in attempt to reduce the development of PGD, including shortening ischaemic time, controlled reperfusion, and various medications and IRI pathway modulations [59-62]; we will discuss this in detail in the next section.

\section{Surgical and anaesthetic consideration in PGD prevention}

\section{Reperfusion considerations}

As described above, repurfusion and ventilation of lung graft are closely linked to the development of IRI and subsequent PGD. Introduction of oxygen to the ischaemic lung graft could result in worsened oxidative stress. The pulmonary vasculature is often constricted which results in pulmonary hypertension, and reperfusion induces a myriad of immune cells which worsens inflammation. This would make the reperfusion process a therapeutic target of preventing PGD $[57,63]$. Due to pulmonary vascular constriction, a sudden restoration of circulation can result in sharp increase in the pulmonary artery pressure. A few studies have looked into the effect of varying rates of reperfusion on the function of the lung graft, and found that initial perfusion the lung graft at a lower flow rate is associated with significantly less pulmonary oedema and reduced shunting, which results in improved lung compliance and gas exchange [64-67].

Indeed, Ardehal et al. conducted a clinical study where the lung graft was perfused with of a modified perfusate via pressure-controlled delivery for $10 \mathrm{~min}$, before pulmonary blood flow was re-established. They reported that the modified perfusion was associated with a significantly lower rate of PGD [63].

In addition to the pressure-controlled delivery, Ardehal also reported a number of modifications to the perfusate, this includes leucodepletion [63]. There are also animal studies which suggest that leucodepletion during both ex vivo lung perfusion (EVLP) and reperfusion after engraftment results in improved graft function $[68,69]$.

Diamond et al. conducted a multicentre retrospective study of 1255 lung transplant patients, and found that the only significant perioperative risk factors associated with PGD were $\mathrm{FiO}_{2}$ during reperfusion, single lung transplant and cardiopulmonary bypass. The study went on further to illustrate that the odd ratio for PGD increases by $10 \%$ for every $10 \%$ increase in $\mathrm{FiO}_{2}$ at the time of reperfusion [57]. While the authors acknowledged that high oxygen requirement is an indication of poor graft function, they also commented that the observed variation of reperfusion $\mathrm{FiO}_{2}$ may be partly due to clinician preference and suggested judicious $\mathrm{FiO}_{2}$ setting may be a modifiable risk factor in PGD. Studies 
directly comparing liberal vs restrictive oxygen therapy at the time of reperfusion are warranted.

\section{Inhaled nitric oxide}

Nitric oxide is known to possess vasodilatory effect to blood vessels by relaxing smooth muscle cells through increasing cGMP. It was thought that inhaled nitric oxide (iNO) may bring localised, vasodilatory effect to pulmonary vasculature, improving oxygenation [70, 71]. Clinical studies have showed the use of iNO in acute respiratory distress syndrome (ARDS) is associated with improved oxygenation, although no impact on mortality is observed [72]. Some evidence showed that iNO may be beneficial on the prevention and treatment of PGD in lung transplantation. A small study that included 6 patients has shown that the administration of iNO immediately after lung transplant reduces pulmonary artery pressure and improves oxygenation [73] Another study investigated the effect of postoperative administration of iNO for a period of $84 \mathrm{~h}$ on average, on those who had already developed PGD. It showed that iNO improves the arterial oxygenation and reduces pulmonary artery pressure [70]. In contrast, a randomised controlled trial showed that iNO may not be beneficial in treatment of PGD [74]. In one study, iNO or placebo were administered 10 min after the reperfusion at lung transplantation. It showed that there is no difference on $\mathrm{PaO}_{2} / \mathrm{FiO}_{2}$ ratio, successful extubation and intensive care unit discharge time or 30-day postoperative mortality [74]. Studies also focused on the preventative role of iNO on PGD. Evidence has shown that prophylactic iNO does not prevent the development of PGD but may improve oxygenation in those who have already developed PGD [75]. A similar result was also seen in a study that looked in the effect of prophylactic use of iNO during the first $30 \mathrm{~min}$ of reperfusion showed no impact on preventing PGD [76] Another randomised controlled trial study also showed that prophylactic iNO has no impact on the development of pulmonary oedema [77]. iNO exposure could theoretically lead to the formation of methaemoglobin (MetHb), but the risk of significant methaemoglobinaemia is minimal at the therapeutic doses. A Cochrane review of 679 patients who received iNO therapy reported 4 cases where MetHb were above 5\% [72]. On the other hand, the risk of iNO induced methaemoglobinaemia in children may be significant [78]. In addition, there have been cases of renal failure observed with iNO exposure [70, 72].

\section{Inhaled prostaglandin}

Prostaglandin (PGE1) can cause vasodilation by increasing the intracellular cyclic adenosine monophosphate (cAMP) [79]. Similar to iNO, it was thought that inhaled PGE1 may bring vasodilatory effect to the lungs and improve oxygenation [80]. PGE1 may also reduce the expression of proinflammatory mediators such as TNF- $\alpha$, IL12; and promote expression of IL 10 after IRI [81]. Other studies have reported that PGE1 reduces the expression of vascular adhesion molecules and monocyte recruitment, while increasing the expression of IL $6[82,83]$. A meta-analysis of 25 studies has suggested that inhaled PGE1 may improve oxygenation in patients with ARDS [84]. A study evaluated the effect of intraoperative administration of aerosol PGE1 during lung transplantation. Compared to the patient's baseline, an improvement on $\mathrm{PaO}_{2} / \mathrm{FiO}_{2}$ ratio and reduction in pulmonary arterial pressure are observed, whilst the haemodynamics remain unchanged [85]. Another study evaluated the effect of donor PGE1 bolus before cross clamping plus PGE1 addition to the graft preservation fluid, and reported that the intervention is associated with significantly increased long-term survival (odds ratio $=9.8$ ) [86]. It has also been suggested that PGE1 infusion may be beneficial as a rescue treatment in patients with severe PGD [87].

\section{Positive end expiratory pressure (PEEP)}

The use of PEEP as a ventilation strategy has been shown to improve pulmonary gas exchange and oxygenation, decrease work of breathing [88, 89]. Evidence showed that high PEEP may reduce mortality in patients with ARDS [90]. Animal and clinical studies have shown that higher PEEP may also play a role in prevention of PGD after lung transplant. A study was carried out to compare higher and lower PEEP on unilateral lung transplant on pigs. It showed that higher PEEP $\left(10 \mathrm{cmH}_{2} \mathrm{O}\right)$ compared to lower PEEP $\left(5 \mathrm{cmH}_{2} \mathrm{O}\right)$ has an impact on increased compliance and reduced airway resistance, although no difference is observed on $\mathrm{PaO}_{2}$ level [91]. A randomised controlled study investigated the effect of open lung protective ventilation on lung transplant [92]. They compared the control group using $5 \mathrm{cmH}_{2} \mathrm{O}$ PEEP and tidal volume of $6 \mathrm{ml} \mathrm{kg}^{-1}$ for 2 lung ventilation and $4 \mathrm{ml} \mathrm{kg}^{-1}$ for 1 lung ventilation and the study group using pressure-controlled ventilation of $16 \mathrm{cmH}_{2} \mathrm{O}$ with $10 \mathrm{cmH}_{2} \mathrm{O}$ PEEP and recruitment manoeuvres [92]. It was shown that the group with higher PEEP and the use of recruitment manoeuvres is associated with an improvement of $\mathrm{PaO}_{2} /$ $\mathrm{FiO}_{2}$ as well as shorter time for tracheal extubation. However, a prolonged effect on the improvement of $\mathrm{PaO}_{2} / \mathrm{FiO}-$ ${ }_{2}$ was not observed.

\section{$\beta$-Adrenoceptor agonists}

$\beta_{2}$-Adrenoceptors are distributed throughout the lung tissue. $\beta_{2}$-Adrenoceptors agonists are commonly used for its bronchodilating effect; however, other proposed effects of $\beta_{2}$-adrenoceptors agonists include the relaxation of vascular smooth muscle, maintenance of the endothelial barrier, 
and may promote the uptake of alveolar fluid. A number of animal studies have demonstrated that nebulisation of $\beta_{2}$ selective agonists during ventilated EVLP is associated with significantly lower graft vascular resistance, reduced oedema development, better pulmonary compliance and better gas exchange [23, 93-95]. Similar findings have also been observed in animal recipients of the transplant studies [96, 97]. In addition, a study by Sapru et al. [98] found that single-nucleotide polymorphisms (SNP) in the donor $\beta$ adrenoceptor genes are associated with significant variations in the graft viability, with higher viability in SNPs with higher isoprenaline sensitivity [99, 100].

To date, the only human study using $\beta_{2}$ agonist was reported by Ware et al. [73]. They demonstrated that in brain dead critical care patients awaiting transplant work-up, intermittent nebulisation of salbutamol did not result in significant change in the oxygenation or lung compliance. Not surprisingly, significantly more patients in the intervention group developed tachycardia which warranted stopping of the medication [94]. However, it is possible that the effective window of $\beta_{2}$ agonists is limited to the graft storage period; and that higher dose of $\beta_{2}$ agonists may be administered to the isolated lung without the cardiovascular side effects [96, 97]. More human studies are needed to clarify if aggressive $\beta_{2}$ agonist treatments are clinically useful during graft retrieval and implantation process.

\section{Other interventions}

Transfusion-related acute lung injury (TRALI) is defined as acute lung injury within $6 \mathrm{~h}$ after a blood transfusion, and is characterised by radiological pulmonary infiltrate and hypoxia. The risk of TRALI is increased by both intrinsic lung injury (as with surgical manipulation of the graft) and systemic insult (as with cardiopulmonary bypass), thus making lung transplant patients high risk for developing TRALI [101]. In addition, there is a possibility that the antibody from the transfused blood may cross react with the lung graft [102]. Judicious use of blood products, as well as close monitoring is required to minimize the risk.

Non-invasive ventilation (NIV) may also be beneficial in patients who have developed PGD [103]. A study investigated the role of NIV in those who had developed acute respiratory failure after lung transplant. After the administration of NIV for an average of 5 days, improved $\mathrm{PaO}_{2} /$ $\mathrm{FiO}_{2}$ ratio and reduction in $\mathrm{PaCO}_{2}$ were observed [103].

Prone positioning may also be beneficial in protection against PGD. It is possible that ventilating through prone position with the use of non-invasive high-frequency percussion ventilation postoperatively may help with improved gas exchange and mucus clearance [104].

Low-flow venovenous removal of $\mathrm{CO}_{2}$ is a method that removes $20-25 \%$ of carbon dioxide from blood. A small study including 3 patients was carried out to investigate the beneficial role of venovenous removal of $\mathrm{CO}_{2}$. It showed that together with the use of iNO and prostacyclin, a reduction in $\mathrm{PaCO}_{2}$, pulmonary infiltrates and increased $\mathrm{PaO}_{2} /$ $\mathrm{FiO}_{2}$ ratio were observed [105]. Similar results on improved $\mathrm{PaO}_{2} / \mathrm{FiO}_{2}$ ratio and $\mathrm{pH}$ level were also observed in another study, although one patient eventually died [106].

\section{Novel therapies for ischaemia-reperfusion injury}

In the last decade, a number of experimental approaches for minimising IRI have been studied and reported in literature, with varying degrees of success. A summary of the therapies and their effects are summarised in Fig. 1.

\section{Ischaemic pre-conditioning and post-conditioning}

Ischaemic pre-conditioning is a process of transient (seconds to minutes) disruption of blood supply, which is thought to have protective effects against further ischaemia and IRI. It can be carried out directly on the tissue of interest, or carried out remotely on another part of the organism [107, 108]. Ischaemic post-conditioning on the other hand is a process of deliberate, cyclic disruption of blood supply after the initial insult [109], which ideally needs to occur within minutes of the initial insult [110].

In animal models of IRI, both direct and remote ischaemic pre-conditionings, as well as ischaemic post-conditioning have been demonstrated to reduce the extent of the IR injury $[109,111,112]$. Ischaemic conditioning has a myriad of effects on the inflammatory response to IR, it reduces the expression of inflammatory cytokines such as TNF- $\alpha$, IL1b, IL6, CCL2; reduces leucocyte recruitment and extravasation by downregulating ICAM $[107,111,113]$. The reduction in neutrophil chemotaxis and activity also reduces of the production of ROS, as seen by a reduction in MDA and lipid hydroperoxides (LPO) production [27]. In addition, ischaemic conditioning also reduces mediators of apoptosis, including BAX, Caspase, cytochrome $\mathrm{C}$ and Fas ligand [108, 112].

Indeed, ischaemic pre-conditioning and post-condition have both demonstrated protective effects against signs of PGD in animal models of lung transplant. In a rat model of lung transplant, $\mathrm{Hu}$ et al. reported significantly less pulmonary oedema and better gas exchange in animals underwent ischaemic post-conditioning, with 5 cycles if $1 \mathrm{~min}$ occlusion of the pulmonary artery [107]. While Jiang et al. reported significantly less pulmonary oedema and microscopic changes after transplant in animals underwent both direct and remote ischaemic pre-conditioning [49]. 


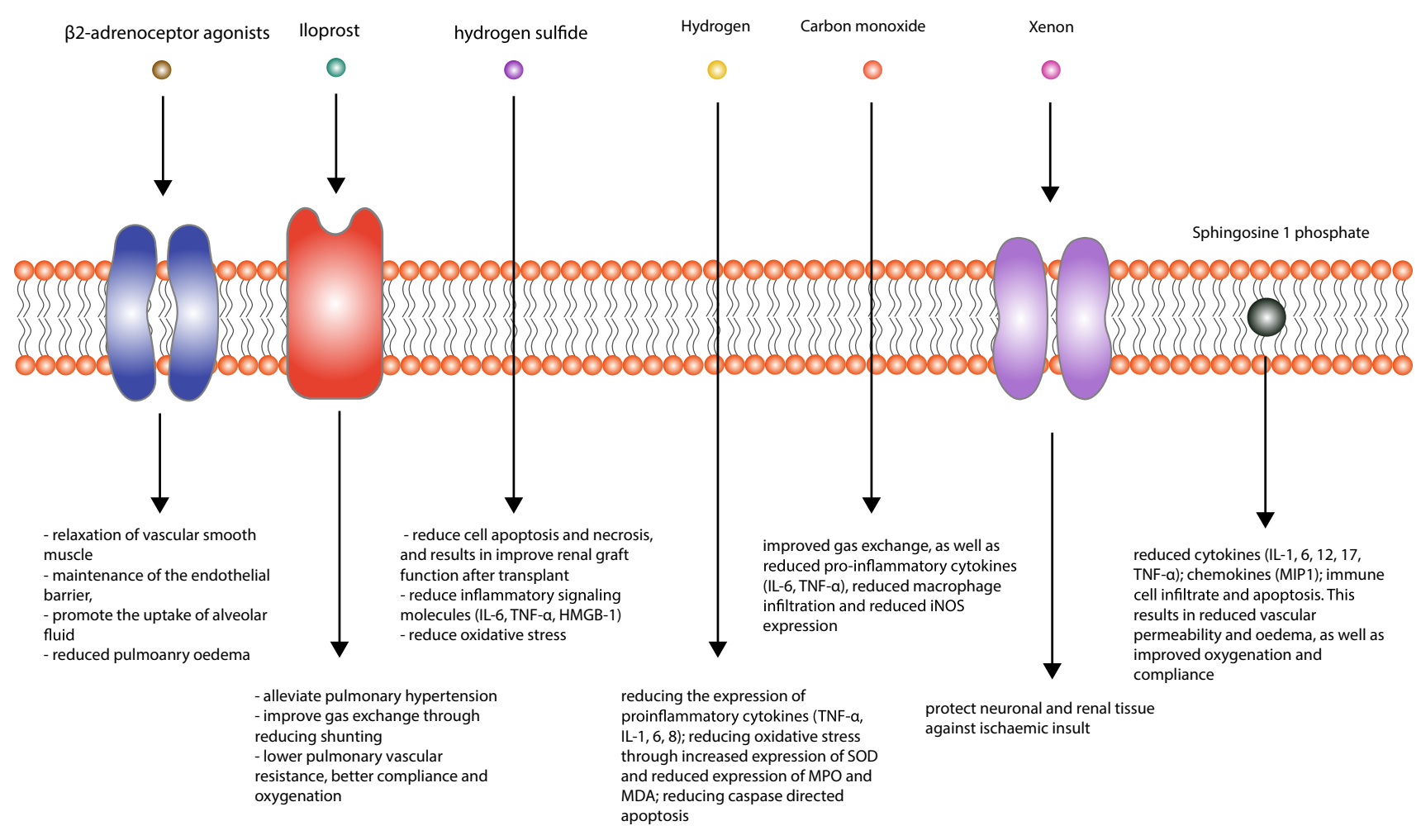

Fig. 1 Potential therapeutic agents for primary graft dysfunction and their mechanisms of action

In 2014, Lin et al. reported a clinical trial of 60 patients who underwent bilateral lung transplant. Patients were randomised to receive either 3 cycles of lower limb ischaemic pre-conditioning prior to the reperfusion, or the control group. They reported a tendency towards higher alveolar-arterial $\mathrm{O}_{2}$ gradient and lower rate of PGD; however, neither were statistically significant [114]. The exact role of ischaemic conditioning on the outcome of lung transplant will need to be explicated through larger clinical trials.

\section{Prostacyclin analogue}

Iloprost is a prostacyclin analogue and a cyclic adenosine monophosphate (cAMP)-mediated pulmonary vasodilator. It is thought that in the context of lung transplant, the pulmonary vasodilatory effect could alleviate pulmonary hypertension and improve gas exchange through reducing shunting [115]. In addition, it is thought to maintain endothelial integrity, and reduce platelet aggregation [116]. Animal studies have shown that when nebulised through the ventilator, or added to the preservative fluid, iloprost administration is associated with better function of the lung graft in the recipient animal, with significantly lower pulmonary vascular resistance, better compliance and oxygenation [45, 46, 117].

In addition, Lee et al. reported that in a cohort of 60 patients, those given nebulised iloprost immediately after reperfusion had significantly lower oxygen requirement and less pulmonary infiltrate, as well as higher compliance [61]. The current literature suggests that iloprost is a promising lung graft protecting agent, and large clinical trials are needed to confirm its benefits.

\section{Hydrogen sulfide donors}

Hydrogen sulfide is a gas with a characteristically pungent odour and is toxic at a high concentration [118]. At a lower concentration, however, it has been shown to have anti-inflammatory, anti-oxidative and anti-apoptotic effects $[119,120]$.

In animal studies, hydrogen sulfide administered through the ventilator, as well as hydrogen sulfide donor sodium hydrosulfide given systemically to the graft recipients have been shown to reduce the expression of pro-inflammatory cytokines, alleviates oxidative stress, and reduce caspase driven apoptosis. This is associated with an increased pulmonary compliance, increased alveolar gas exchange, and reduction in shunting and oedema [121-124].

\section{Other inhaled gases}

Hydrogen gas has been proposed to be a potent free radical scavenger as well as anti-inflammatory agent [125]. In 
animal models, insufflating the lung graft with 2-3\% hydrogen is associated with significantly better compliance and gas exchange, reduced pulmonary vascular resistance and histological changes. This is thought to be mediated through a number of mechanisms, such as reducing the expression of proinflammatory cytokines (TNF- $\alpha$, IL- $1,6,8$ ), reducing oxidative stress and reducing caspase-mediated apoptosis $[24,50,126]$.

Although the mechanism is not clear, carbon monoxide is thought to have potent anti-inflammatory properties [127]. In animal models of lung transplant, insufflating the lung graft with 500PPM carbon monoxide was associated with reduced pro-inflammatory mediators, oxidative stress, and apoptosis mediators. In addition, the transplanted lung grafts demonstrated reduced edema and improved compliance and gas exchange $[8,126]$.

\section{a1-Antitrypsin}

$\alpha_{1}$-Antitrypsin is a protease inhibitor that protects tissue from the proteolytic enzymes produced by inflammatory cells. In addition to the direct inhibitory effect on proteases, it is also thought to have anti-apoptotic properties, regulate macrophage and neutrophil actions, and has been shown to protect against ischaemia/reperfusion injuries in a number of animal models [128].

In animal models of lung transplant, $\alpha_{1}$-antitrypsin administration has been associated with significantly reduced NF- $\kappa B$ expression and neutrophil infiltration, better gas exchange, and better lung compliance $[129,130]$. In addition, in EVLP only and in ischaemia/reperfusion models, $\alpha_{1}$-antitrypsin administration has also been associated with significantly reduced inflammatory cytokine expression, neutrophil infiltration and apoptosis, with better lung compliance [62,131].

\section{Other novel targets}

Sphingosine 1 phosphate (S1P) is a lipid growth factor derived from cell membrane sphingolipids. It has been proposed to promote cell survival, proliferation and angiogenesis [132, 133]. In animal lung transplant models, S1P administration is associated with significantly reduced cytokines, immune cell infiltrate and apoptosis. This results in reduced vascular permeability and oedema, as well as improved oxygenation and compliance [134-136].

Adenosine receptor agonism has been shown to reduce IRI by through its regulatory function on T cells and NK cells [137, 138]. Animal models of IRI have reported that adenosine receptor agonists significantly reduce inflammatory mediator expression, as well as improve lung function [139-143].
Del Sorbo et al. suggested that siRNA against Fas receptor, responsible for apoptosis in ischaemia/reperfusion could reduce graft dysfunction [144].

Necroptosis as a result of the calpain-STAT3-RIPK pathway activation has also been implicated in ischaemia/reperfusion pathology, and it has been suggested that blocking the said pathway may also reduce graft dysfunction [145, 146].

IL-10 is a regulatory cytokine that can inhibit NF- $\mathrm{KB}$ and the JAK/STAT pathways. Upregulation of IL-10 has been implicated in the cytoprotective effect of $\alpha_{1}$-antitrypsin [147], and in animal model of lung transplant, IL-10 gene therapy was associated with significantly better gas exchange [51].

\section{Conclusion}

PGD is a common and potentially life-threatening complication which is thought to be secondary to IRI following engraftment. While there are now clear guidelines on its diagnosis, there are limited preventative and treatment options available. We have discussed in detail the pathophysiology of PGD and highlighted some of the therapeutic options reported in pre-clinical studies, which includes some drugs which are already licensed for clinical use. With the expansion of the pre-clinical evidence, it may be possible for some of those experimental therapies to be developed for clinical use.

Acknowledgements The work was supported by the BJA fellowship Grant (D. Ma), NIAA, London, UK.

\section{Compliance with ethical standards}

Conflict of interest The authors declare that they have no competing interests.

Open Access This article is licensed under a Creative Commons Attribution 4.0 International License, which permits use, sharing, adaptation, distribution and reproduction in any medium or format, as long as you give appropriate credit to the original author(s) and the source, provide a link to the Creative Commons licence, and indicate if changes were made. The images or other third party material in this article are included in the article's Creative Commons licence, unless indicated otherwise in a credit line to the material. If material is not included in the article's Creative Commons licence and your intended use is not permitted by statutory regulation or exceeds the permitted use, you will need to obtain permission directly from the copyright holder. To view a copy of this licence, visit http://creativecommons.org/licenses/by/4.0/.

\section{References}

1. Reitz BA, Wallwork JL, Hunt SA, Pennock JL, Billingham ME, Oyer PE, Stinson EB, Shumway NE. Heart-lung transplantation: 
successful therapy for patients with pulmonary vascular disease. N Engl J Med. 1982;306(10):557-64.

2. Chambers DC, Yusen RD, Cherikh WS, Goldfarb SB, Kucheryavaya AY, Khusch K, Levvey BJ, Lund LH, Meiser B, Rossano JW, Stehlik J. The Registry of the International Society for Heart and Lung Transplantation: thirty-fourth adult lung and heart-lung transplantation report-2017; focus theme: allograft ischemic time. J Heart Lung Transplant. 2017;36(10):1047-59.

3. Meyer DM, Edwards LB, Torres F, Jessen ME, Novick RJ. Impact of recipient age and procedure type on survival after lung transplantation for pulmonary fibrosis. Ann Thorac Surg. 2005;79(3):950-7 (discussion 7-8).

4. Christie JD, Kotloff RM, Ahya VN, Tino G, Pochettino A, Gaughan C, DeMissie E, Kimmel SE. The effect of primary graft dysfunction on survival after lung transplantation. Am J Respir Crit Care Med. 2005;171(11):1312-6.

5. Snell GI, Yusen RD, Weill D, Strueber M, Garrity E, Reed A, Pelaez A, Whelan TP, Perch M, Bag R, Budev M, Corris PA, Crespo MM, Witt C, Cantu E, Christie JD. Report of the ISHLT Working Group on Primary Lung Graft Dysfunction, part I: definition and grading-A 2016 consensus group statement of the International Society for Heart and Lung Transplantation. J Heart Lung Transplant. 2017;36(10):1097-103.

6. Christie JD, Carby M, Bag R, Corris P, Hertz M, Weill D. Report of the ISHLT Working Group on Primary Lung Graft Dysfunction part II: definition. A consensus statement of the International Society for Heart and Lung Transplantation. J Heart Lung Transplant. 2005;24(10):1454-9.

7. Prekker ME, Nath DS, Walker AR, Johnson AC, Hertz MI, Herrington CS, Radosevich DM, Dahlberg PS. Validation of the proposed International Society for Heart and Lung Transplantation grading system for primary graft dysfunction after lung transplantation. J Heart Lung Transplant. 2006;25(4):371-8.

8. Meng C, Ma L, Liu J, Cui X, Liu R, Xing J, Zhou H. Inflation with carbon monoxide in rat donor lung during cold ischemia phase ameliorates graft injury. Exp Biol Med (Maywood). 2016;241(3):246-54.

9. Emaminia A, Lapar DJ, Zhao Y, Steidle JF, Harris DA, Laubach VE, Linden J, Kron IL, Lau CL. Adenosine A(2)A agonist improves lung function during ex vivo lung perfusion. Ann Thorac Surg. 2011;92(5):1840-6.

10. Glorion M, Polard V, Favereau F, Hauet T, Zal F, Fadel E, Sage E. Prevention of ischemia-reperfusion lung injury during static cold preservation by supplementation of standard preservation solution with HEMO2life((R)) in pig lung transplantation model. Artif Cells Nanomed Biotechnol. 2017;46(8):1773-800.

11. de Perrot M, Liu M, Waddell TK, Keshavjee S. Ischemiareperfusion-induced lung injury. Am J Respir Crit Care Med. 2003;167(4):490-511.

12. Abela CB, Homer-Vanniasinkham S. Clinical implications of ischaemia-reperfusion injury. Pathophysiology. 2003;9(4):229-40.

13. Collard CD, Gelman S. Pathophysiology, clinical manifestations, and prevention of ischemia-reperfusion injury. Anesthesiology. 2001;94(6):1133-8.

14. Liu X, Cao H, Li J, Wang B, Zhang P, Dong Zhang X, Liu Z, Yuan H, Zhan Z. Autophagy induced by DAMPs facilitates the inflammation response in lungs undergoing ischemia-reperfusion injury through promoting TRAF6 ubiquitination. Cell Death Differ. 2017;24(4):683-93.

15. Sharma AK, Mulloy DP, Le LT, Laubach VE. NADPH oxidase mediates synergistic effects of IL-17 and TNF-alpha on CXCL1 expression by epithelial cells after lung ischemia-reperfusion. Am J Physiol Lung Cell Mol Physiol. 2014;306(1):L69-79.
16. He Q, Zhao X, Bi S, Cao Y. Pretreatment with erythropoietin attenuates lung ischemia/reperfusion injury via toll-like receptor-4/nuclear factor-kappaB (TLR4/NF-kappaB) pathway. Med Sci Monit. 2018;24:1251-7.

17. Chatterjee S, Nieman GF, Christie JD, Fisher AB. Shear stressrelated mechanosignaling with lung ischemia: lessons from basic research can inform lung transplantation. Am J Physiol Lung Cell Mol Physiol. 2014;307(9):L668-L680.

18. Hidalgo MA, Sarathchandra P, Fryer PR, Fuller BJ, Green CJ. Scanning electron microscopic changes in morphology of pulmonary endothelium in rat lung isografts following hypothermic ischaemic storage and transplantation. Int J Exp Pathol. 1995;76(5):339-51.

19. Hidalgo MA, Shah KA, Fuller BJ, Green CJ. Cold ischemiainduced damage to vascular endothelium results in permeability alterations in transplanted lungs. J Thorac Cardiovasc Surg. 1996;112(4):1027-35.

20. Fullerton DA, Mitchell MB, McIntyre RC Jr, Banerjee A, Campbell DN, Harken AH, Grover FL. Cold ischemia and reperfusion each produce pulmonary vasomotor dysfunction in the transplanted lung. J Thorac Cardiovasc Surg. 1993;106(6):1213-7.

21. De Leyn PR, Lerut TE, Schreinemakers HH, Van Raemdonck DE, Mubagwa K, Flameng W. Effect of inflation on adenosine triphosphate catabolism and lactate production during normothermic lung ischemia. Ann Thorac Surg. 1993;55(5):1073-8 (discussion 9).

22. Yang Z, Sharma AK, Marshall M, Kron IL, Laubach VE. NADPH oxidase in bone marrow-derived cells mediates pulmonary ischemia-reperfusion injury. Am J Respir Cell Mol Biol. 2009;40(3):375-81.

23. Chen F, Nakamura T, Fujinaga T, Zhang J, Hamakawa H, Omasa M, Sakai H, Hanaoka N, Bando T, Wada H, Fukuse T. Protective effect of a nebulized beta2-adrenoreceptor agonist in warm ischemic-reperfused rat lungs. Ann Thorac Surg. 2006;82(2):465-71.

24. Liu R, Fang X, Meng C, Xing J, Liu J, Yang W, Li W, Zhou H. Lung inflation with hydrogen during the cold ischemia phase decreases lung graft injury in rats. Exp Biol Med (Maywood). 2015;240(9):1214-22.

25. Kim H, Zamel R, Bai XH, Lu C, Keshavjee S, Liu M. Ischemia reperfusion induces death receptor-independent necroptosis via calpain-STAT3 activation in a lung transplant setting. Am J Physiol Lung Cell Mol Physiol. 2018;315(4):L595-L608

26. Zhao X, Jin Y, Li H, Wang Z, Zhang W, Feng C. Hypoxia-inducible factor 1 alpha contributes to pulmonary vascular dysfunction in lung ischemia-reperfusion injury. Int J Clin Exp Pathol. 2014;7(6):3081-8

27. Simon C, Vara E, Garutti I, Gonzalez-Casaurran G, Azcarate L, Isea J, Huerta L, Gonzalez-Aragoneses F. Modulation of monocyte chemoattractant protein-1 expression by ischaemic preconditioning in a lung autotransplant model. Eur J Cardiothorac Surg. 2012;41(4):933-9.

28. Winterbourn CC, Kettle AJ, Hampton MB. Reactive oxygen species and neutrophil function. Annu Rev Biochem. 2016;85:765-92.

29. Nishino T. The conversion of xanthine dehydrogenase to xanthine oxidase and the role of the enzyme in reperfusion injury. $\mathbf{J}$ Biochem. 1994;116(1):1-6.

30. Kayyali US, Donaldson C, Huang H, Abdelnour R, Hassoun PM. Phosphorylation of xanthine dehydrogenase/oxidase in hypoxia. J Biol Chem. 2001;276(17):14359-65.

31. Phan SH, Gannon DE, Ward PA, Karmiol S. Mechanism of neutrophil-induced xanthine dehydrogenase to xanthine oxidase conversion in endothelial cells: evidence of a role for elastase. Am J Respir Cell Mol Biol. 1992;6(3):270-8. 
32. Adkins WK, Taylor AE. Role of xanthine oxidase and neutrophils in ischemia-reperfusion injury in rabbit lung. J Appl Physiol (1985). 1990;69(6):2012-8.

33. Gielis JF, Lin JY, Wingler K, Van Schil PE, Schmidt HH, Moens AL. Pathogenetic role of eNOS uncoupling in cardiopulmonary disorders. Free Radic Biol Med. 2011;50(7):765-76.

34. Gielis JF, Quirynen L, Briede JJ, Roelant E, Cos P, Van Schil PEY. Pathogenetic role of endothelial nitric oxide synthase uncoupling during lung ischaemia-reperfusion injury. Eur $\mathbf{J}$ Cardiothorac Surg. 2017;52(2):256-63.

35. Bloodsworth A, O'Donnell VB, Freeman BA. Nitric oxide regulation of free radical- and enzyme-mediated lipid and lipoprotein oxidation. Arterioscler Thromb Vasc Biol. 2000;20(7):1707-15.

36. Rancan L, Paredes SD, Huerta L, Casanova J, Guzman J, Garutti I, Gonzalez-Aragoneses F, Simon C, Vara E. Chemokine involvement in lung injury secondary to ischaemia/reperfusion. Lung. 2017;195(3):333-40.

37. Casanova J, Simon C, Vara E, Sanchez G, Rancan L, Abubakra S, Calvo A, Gonzalez FJ, Garutti I. Sevoflurane anesthetic preconditioning protects the lung endothelial glycocalyx from ischemia reperfusion injury in an experimental lung autotransplant model. J Anesth. 2016;30(5):755-62.

38. Mallavia B, Liu F, Sheppard D, Looney MR. Inhibiting integrin alphavbeta5 reduces ischemia-reperfusion injury in an orthotopic lung transplant model in mice. Am J Transplant. 2016;16(4):1306-11.

39. Lawrence T. The nuclear factor NF-kappaB pathway in inflammation. Cold Spring Harb Perspect Biol. 2009;1(6):a001651.

40. Harada M, Oto T, Otani S, Miyoshi K, Okada M, Iga N, Nishikawa H, Sugimoto S, Yamane M, Miyoshi S. A neutrophil elastase inhibitor improves lung function during ex vivo lung perfusion. Gen Thorac Cardiovasc Surg. 2015;63(12):645-51.

41. Sharma AK, LaPar DJ, Zhao Y, Li L, Lau CL, Kron IL, Iwakura Y, Okusa MD, Laubach VE. Natural killer T cell-derived IL-17 mediates lung ischemia-reperfusion injury. Am J Respir Crit Care Med. 2011;183(11):1539-49.

42. Dodd OJ, Pearse DB. Effect of the NADPH oxidase inhibitor apocynin on ischemia-reperfusion lung injury. Am J Physiol Heart Circ Physiol. 2000;279(1):H303-H312312.

43. DiStasi MR, Ley K. Opening the flood-gates: how neutrophilendothelial interactions regulate permeability. Trends Immunol. 2009;30(11):547-56.

44. Hofmann S, Grasberger H, Jung P, Bidlingmaier M, Vlotides J, Janssen OE, Landgraf R. The tumour necrosis factor-alpha induced vascular permeability is associated with a reduction of VE-cadherin expression. Eur J Med Res. 2002;7(4):171-6.

45. Gohrbandt B, Sommer SP, Fischer S, Hohlfeld JM, Warnecke G, Haverich A, Strueber M. Iloprost to improve surfactant function in porcine pulmonary grafts stored for twenty-four hours in low-potassium dextran solution. J Thorac Cardiovasc Surg. 2005;129(1):80-6.

46. Wittwer T, Franke UF, Fehrenbach A, Ochs M, Sandhaus T, Schuette A, Richter S, Dreyer N, Knudsen L, Muller T, Schubert H, Richter J, Wahlers T. Donor pretreatment using the aerosolized prostacyclin analogue iloprost optimizes post-ischemic function of non-heart beating donor lungs. J Heart Lung Transplant. 2005;24(4):371-8.

47. Kandilci HB, Gumusel B, Demiryurek AT, Lippton H. Preconditioning modulates pulmonary endothelial dysfunction following ischemia-reperfusion injury in the rat lung: role of potassium channels. Life Sci. 2006;79(23):2172-8.

48. Jin Y, Zhao X, Zhang H, Li Q, Lu G. Modulatory effect of silymarin on pulmonary vascular dysfunction through HIF-1alphaiNOS following rat lung ischemia-reperfusion injury. Exp Ther Med. 2016;12(2):1135-40.
49. Jiang T, Liu Y, Ma M, Zong L, Yiliyaer X, Zhang H, Zhu H. The role of remote ischemic preconditioning in ischemia-reperfusion injury in rabbits with transplanted lung. Clin Lab. 2015;61(5-6):481-6.

50. Haam S, Lee S, Paik HC, Park MS, Song JH, Lim BJ, Nakao A. The effects of hydrogen gas inhalation during ex vivo lung perfusion on donor lungs obtained after cardiac death. Eur J Cardiothorac Surg. 2015;48(4):542-7.

51. Machuca TN, Cypel M, Bonato R, Yeung JC, Chun YM, Juvet S, Guan Z, Hwang DM, Chen M, Saito T, Harmantas C, Davidson BL, Waddell TK, Liu M, Keshavjee S. Safety and efficacy of ex vivo donor lung adenoviral IL-10 gene therapy in a large animal lung transplant survival model. Hum Gene Ther. 2017;28(9):757-65.

52. Kuntz CL, Hadjiliadis D, Ahya VN, Kotloff RM, Pochettino A, Lewis J, Christie JD. Risk factors for early primary graft dysfunction after lung transplantation: a registry study. Clin Transplant. 2009;23(6):819-30.

53. Samano MN, Fernandes LM, Baranauskas JC, Correia AT, Afonso JE Jr, Teixeira RH, Caramori ML, Pego-Fernandes PM, Jatene FB. Risk factors and survival impact of primary graft dysfunction after lung transplantation in a single institution. Transplant Proc. 2012;44(8):2462-8.

54. Diamond JM, Arcasoy S, Kennedy CC, Eberlein M, Singer JP, Patterson GM, Edelman JD, Dhillon G, Pena T, Kawut SM, Lee JC, Girgis R, Dark J, Thabut G. Report of the International Society for Heart and Lung Transplantation Working Group on Primary Lung Graft Dysfunction, part II: epidemiology, risk factors, and outcomes-A 2016 Consensus Group statement of the International Society for Heart and Lung Transplantation. J Heart Lung Transplant. 2017;36(10):1104-13.

55. Liu Y, Su L, Jiang SJ. Recipient-related clinical risk factors for primary graft dysfunction after lung transplantation: a systematic review and meta-analysis. PLoS ONE. 2014;9(3):e92773.

56. Whitson BA, Nath DS, Johnson AC, Walker AR, Prekker ME, Radosevich DM, Herrington CS, Dahlberg PS. Risk factors for primary graft dysfunction after lung transplantation. J Thorac Cardiovasc Surg. 2006;131(1):73-80.

57. Diamond JM, Lee JC, Kawut SM, Shah RJ, Localio AR, Bellamy SL, Lederer DJ, Cantu E, Kohl BA, Lama VN, Bhorade SM, Crespo M, Demissie E, Sonett J, Wille K, Orens J, Shah AS, Weinacker A, Arcasoy S, Shah PD, Wilkes DS, Ware LB, Palmer SM, Christie JD. Clinical risk factors for primary graft dysfunction after lung transplantation. Am J Respir Crit Care Med. 2013;187(5):527-34.

58. Lund L, Khush K, Cherikh W, Goldfarb S, Kucheryavaya A, Levvey B, Meiser B, Rossano J, Chambers D, Yusen R, Stehlik J. The Registry of the International Society for Heart and Lung Transplantation: thirty-fourth adult heart transplantation report-2017; focus theme: allograft ischemic time. J Heart Lung Transplant. 2017;36(10):1037-46.

59. Ruttens D, Martens A, Ordies S, Verleden SE, Neyrinck AP, Vos R, Boada MC, Vanaudenaerde BM, Verleden GM, Van Raemdonck D. Short- and long-term outcomes after lung transplantation from circulatory-dead donors: a single-center experience. Transplantation. 2017;101(11):2691-4.

60. Van Raemdonck D, Hartwig MG, Hertz MI, Davis RD, Cypel M, Hayes D Jr, Ivulich S, Kukreja J, Lease ED, Loor G, Mercier O, Paoletti L, Parmar J, Rampolla R, Wille K, Walia R, Keshavjee S. Report of the ISHLT Working Group on primary lung graft dysfunction part IV: prevention and treatment: a 2016 Consensus Group statement of the International Society for Heart and Lung Transplantation. J Heart Lung Transplant. 2017;36(10):1121-36.

61. Lee SH, Lee JG, Lee CY, Kim N, Chang MY, You YC, Kim HJ, Paik HC, Oh YJ. Effects of intraoperative inhaled 
iloprost on primary graft dysfunction after lung transplantation: a retrospective single center study. Medicine (Baltimore). 2016;95(27):e3975.

62. Gao W, Zhao J, Kim H, Xu S, Chen M, Bai X, Toba H, Cho HR, Zhang H, Keshavjeel S, Liu M. Alpha1-antitrypsin inhibits ischemia reperfusion-induced lung injury by reducing inflammatory response and cell death. J Heart Lung Transplant. 2014;33(3):309-15.

63. Ardehali A, Laks H, Russell H, Levine M, Shpiner R, Lackey $\mathrm{S}$, Ross D. Modified reperfusion and ischemia-reperfusion injury in human lung transplantation. J Thorac Cardiovasc Surg. 2003;126(6):1929-34.

64. Tanaka H, Chiba Y, Sasaki M, Matsukawa S, Muraoka R. Relationship between flushing pressure and nitric oxide production in preserved lungs. Transplantation. 1998;65(4):460-4.

65. Pierre AF, DeCampos KN, Liu M, Edwards V, Cutz E, Slutsky AS, Keshavjee SH. Rapid reperfusion causes stress failure in ischemic rat lungs. J Thorac Cardiovasc Surg. 1998;116(6):932-42.

66. Fiser SM, Tribble CG, Kern JA, Long SM, Kaza AK, Kron IL. Controlled perfusion decreases lung transplant reperfusion injury in the setting of high flow reperfusion. J Heart Lung Transplant. 2001;20(2):183.

67. Guth S, Prufer D, Kramm T, Mayer E. Length of pressurecontrolled reperfusion is critical for reducing ischaemia-reperfusion injury in an isolated rabbit lung model. J Cardiothorac Surg. 2007;2:54.

68. Kagawa H, Morita K, Nagahori R, Shinohara G, Kinouchi K, Hashimoto K. Prevention of ischemia/reperfusion-induced pulmonary dysfunction after cardiopulmonary bypass with terminal leukocyte-depleted lung reperfusion. J Thorac Cardiovasc Surg. 2010;139(1):174-80.

69. Noda K, Tane S, Haam SJ, D'Cunha J, Hayanga AJ, Luketich JD, Shigemura N. Targeting circulating leukocytes and pyroptosis during ex vivo lung perfusion improves lung preservation. Transplantation. 2017;101(12):2841-9.

70. Date H, Triantafillou AN, Trulock EP, Pohl MS, Cooper JD, Patterson GA. Inhaled nitric oxide reduces human lung allograft dysfunction. J Thorac Cardiovasc Surg. 1996;111(5):913-9.

71. Akmal AH, Hasan M. Role of nitric oxide in management of acute respiratory distress syndrome. Ann Thorac Med. 2008;3(3):100-3.

72. Gebistorf F, Karam O, Wetterslev J, Afshari A. Inhaled nitric oxide for acute respiratory distress syndrome (ARDS) in children and adults. Cochrane Database Syst Rev. 2016;6:Cd002787.

73. Adatia I, Lillehei C, Arnold JH, Thompson JE, Palazzo R, Fackler JC, Wessel DL. Inhaled nitric oxide in the treatment of postoperative graft dysfunction after lung transplantation. Ann Thorac Surg. 1994;57(5):1311-8.

74. Meade MO, Granton JT, Matte-Martyn A, McRae K, Weaver B, Cripps P, Keshavjee SH. A randomized trial of inhaled nitric oxide to prevent ischemia-reperfusion injury after lung transplantation. Am J Respir Crit Care Med. 2003;167(11):1483-9.

75. Ardehali A, Laks H, Levine M, Shpiner R, Ross D, Watson LD, Shvartz O, Sangwan S, Waters PF. A prospective trial of inhaled nitric oxide in clinical lung transplantation. Transplantation. 2001;72(1):112-5.

76. Botha P, Jeyakanthan M, Rao JN, Fisher AJ, Prabhu M, Dark JH, Clark SC. Inhaled nitric oxide for modulation of ischemia-reperfusion injury in lung transplantation. J Heart Lung Transplant. 2007;26(11):1199-205.

77. Perrin G, Roch A, Michelet P, Reynaud-Gaubert M, Thomas P, Doddoli C, Auffray JP. Inhaled nitric oxide does not prevent pulmonary edema after lung transplantation measured by lung water content: a randomized clinical study. Chest. 2006;129(4):1024-30

78. Conroy AL, Hawkes M, Hayford K, Hermann L, McDonald CR, Sharma S, Namasopo S, Opoka RO, John CC, Liles WC, Miller C, Kain KC. Methemoglobin and nitric oxide therapy in Ugandan children hospitalized for febrile illness: results from a prospective cohort study and randomized double-blind placebo-controlled trial. BMC Pediatr. 2016;16(1):177.

79. Ricciotti E, FitzGerald GA. Prostaglandins and inflammation. Arterioscler Thromb Vasc Biol. 2011;31(5):986-1000.

80. Meyer J, Theilmeier G, Van Aken H, Bone HG, Busse H, Waurick R, Hinder F, Booke M. Inhaled prostaglandin E1 for treatment of acute lung injury in severe multiple organ failure. Anesth Analg. 1998;86(4):753-8.

81. de Perrot M, Fischer S, Liu M, Jin R, Bai XH, Waddell TK, Keshavjee S. Prostaglandin E protects lung transplants from ischemia-reperfusion injury: a shift from pro- to anti-inflammatory cytokines. Transplantation. 2001;72(9):1505-12

82. Farrokhnia E, Makarem J, Khan ZH, Mohagheghi M, Maghsoudlou M, Abdollahi A. The effects of prostaglandin E1 on interleukin-6, pulmonary function and postoperative recovery in oesophagectomised patients. Anaesth Intensive Care. 2009;37(6):937-43.

83. Fang W, Li H, Zhou L, Su L, Liang Y, Mu Y. Effect of prostaglandin E1 on TNF-induced vascular inflammation in human umbilical vein endothelial cells. Can J Physiol Pharmacol. 2010;88(5):131-9.

84. Fuller BM, Mohr NM, Skrupky L, Fowler S, Kollef MH, Carpenter CR. The use of inhaled prostaglandins in patients with ARDS: a systematic review and meta-analysis. Chest. 2015;147(6):1510-22.

85. Della Rocca G, Coccia C, Pompei L, Costa MG, Di Marco P, Pietropaoli P. Inhaled aerosolized prostaglandin E1, pulmonary hemodynamics, and oxygenation during lung transplantation. Minerva Anestesiol. 2008;74(11):627-33.

86. Toyoda Y, Thacker J, Santos R, Nguyen D, Bhama J, Bermudez C, Kormos R, Johnson B, Crespo M, Pilewski J, Teuteberg J, Alvarez R, Mathier M, McNamara D, McCurry K, Zenati M, Hattler B. Long-term outcome of lung and heart-lung transplantation for idiopathic pulmonary arterial hypertension. Ann Thorac Surg. 2008;86(4):1116-22.

87. Yeung JC, Keshavjee S. Overview of clinical lung transplantation. Cold Spring Harbor Perspect Med. 2014;4(1):a015628

88. Rossi A, Santos C, Roca J, Torres A, Felez MA, RodriguezRoisin R. Effects of PEEP on VA/Q mismatching in ventilated patients with chronic airflow obstruction. Am J Respir Crit Care Med. 1994;149(5):1077-84.

89. Smith TC, Marini JJ. Impact of PEEP on lung mechanics and work of breathing in severe airflow obstruction. J Appl Physiol (1985). 1988;65(4):1488-99.

90. Guo L, Xie J, Huang Y, Pan C, Yang Y, Qiu H, Liu L. Higher PEEP improves outcomes in ARDS patients with clinically objective positive oxygenation response to PEEP: a systematic review and meta-analysis. BMC Anesthesiol. 2018;18(1):172.

91. Madke GR, Forgiarini LA Jr, Grun G, Fontena E, Pereira RB, de Moraes MM, Mariano R, Cardoso PF, Felix EA, Andrade CF. Effect of positive end-expiratory pressure after porcine unilateral left lung transplant. Exp Clin Transplant. 2013;11(1):50-5.

92. Verbeek GL, Myles PS, Westall GP, Lin E, Hastings SL, Marasco SF, Jaffar J, Meehan AC. Intra-operative protective mechanical ventilation in lung transplantation: a randomised, controlled trial. Anaesthesia. 2017;72(8):993-1004.

93. Valenza F, Rosso L, Coppola S, Froio S, Colombo J, Dossi R, Fumagalli J, Salice V, Pizzocri M, Conte G, Gatti S, Santambrogio L, Gattinoni L. beta-adrenergic agonist infusion during extracorporeal lung perfusion: effects on glucose concentration 
in the perfusion fluid and on lung function. J Heart Lung Transplant. 2012;31(5):524-30.

94. Ware LB, Landeck M, Koyama T, Zhao Z, Singer J, Kern R, Neidlinger N, Nguyen J, Johnson E, Janz DR, Bernard GR, Lee JW, Matthay MA. A randomized trial of the effects of nebulized albuterol on pulmonary edema in brain-dead organ donors. Am J Transplant. 2014;14(3):621-8.

95. Kondo T, Chen F, Ohsumi A, Hijiya K, Motoyama H, Sowa T, Ohata K, Takahashi M, Yamada T, Sato M, Aoyama A, Date H. Beta2-adrenoreceptor agonist inhalation during ex vivo lung perfusion attenuates lung injury. Ann Thorac Surg. 2015;100(2):480-6.

96. Hijiya K, Chen-Yoshikawa TF, Kondo T, Motoyama H, Ohsumi A, Nakajima D, Sakamoto J, Ohata K, Takahashi M, Tanaka S, Miyamoto E, Aoyama A, Date H. Bronchodilator inhalation during ex vivo lung perfusion improves posttransplant graft function after warm ischemia. Ann Thorac Surg. 2017;103(2):447-53.

97. Sakamoto J, Chen F, Nakajima D, Yamada T, Ohsumi A, Zhao $\mathrm{X}$, Sakai H, Bando T, Date H. The effect of beta-2 adrenoreceptor agonist inhalation on lungs donated after cardiac death in a canine lung transplantation model. J Heart Lung Transplant. 2012;31(7):773-9.

98. Sapru A, Pawlikowska L, Liu KD, Khush KK, Ann-BaxterLowe L, Hayden V, Menza RL, Convery M, Poon A, Landeck M, Zaroff JG, Matthay MA. Single-nucleotide polymorphisms in the beta-adrenergic receptor genes are associated with lung allograft utilization. J Heart Lung Transplant. 2011;30(2):211-7.

99. Zhang F, Steinberg SF. S49G and R389G polymorphisms of the beta(1)-adrenergic receptor influence signaling via the cAMPPKA and ERK pathways. Physiol Genom. 2013;45(23):1186-92.

100. Mason DA, Moore JD, Green SA, Liggett SB. A gain-of-function polymorphism in a G-protein coupling domain of the human beta1-adrenergic receptor. J Biol Chem. 1999;274(18):12670-4.

101. Kleinman S, Caulfield T, Chan P, Davenport R, McFarland J, McPhedran S, Meade M, Morrison D, Pinsent T, Robillard $\mathrm{P}$, Slinger P. Toward an understanding of transfusion-related acute lung injury: statement of a consensus panel. Transfusion. 2004;44(12):1774-899.

102. Dykes A, Smallwood D, Kotsimbos T, Street A. Transfusionrelated acute lung injury (Trali) in a patient with a single lung transplant. Br J Haematol. 2000;109(3):674-6.

103. Rocco M, Conti G, Antonelli M, Bufi M, Costa MG, Alampi D, Ruberto F, Stazi GV, Pietropaoli P. Non-invasive pressure support ventilation in patients with acute respiratory failure after bilateral lung transplantation. Intensive Care Med. 2001;27(10):1622-6.

104. Feltracco P, Serra E, Barbieri S, Milevoj M, Michieletto E, Carollo C, Rea F, Zanus G, Boetto R, Ori C. Noninvasive highfrequency percussive ventilation in the prone position after lung transplantation. Transplant Proc. 2012;44(7):2016-21.

105. Ruberto F, Bergantino B, Testa MC, D'Arena C, Zullino V, Congi P, Paglialunga SG, Diso D, Venuta F, Pugliese F. Low-flow venovenous $\mathrm{CO}(2)$ removal in association with lung protective ventilation strategy in patients who develop severe progressive respiratory acidosis after lung transplantation. Transplant Proc. 2013;45(7):2741-5.

106. Ruberto F, Bergantino B, Testa MC, D'Arena C, Bernardinetti M, Diso D, De Giacomo T, Venuta F, Pugliese F. Low-flow venovenous extracorporeal $\mathrm{CO}_{2}$ removal: first clinical experience in lung transplant recipients. Int J Artif Organs. 2014;37(12):911-7.

107. Hu QH, Luo FY, Luo WJ, Wang L. Ischemic postconditioning reduces ischemic reperfusion injury of non-heart-beating donor grafts in a rat lung transplant. Exp Clin Transplant. 2013;11(1):44-9.

108. Huerta L, Rancan L, Simon C, Isea J, Vidaurre E, Vara E, Garutti I, Gonzalez-Aragoneses F. Ischaemic preconditioning prevents the liver inflammatory response to lung ischaemia/reperfusion in a swine lung autotransplant model. Eur J Cardiothorac Surg. 2013;43(6):1194-201.

109. Waldow T, Alexiou K, Witt W, Albrecht S, Wagner F, Knaut $\mathrm{M}$, Matschke K. Protection against acute porcine lung ischemia/ reperfusion injury by systemic preconditioning via hind limb ischemia. Transpl Int. 2005;18(2):198-205.

110. Jivraj N, Liew F, Marber M. Ischaemic postconditioning: cardiac protection after the event. Anaesthesia. 2015;70(5):598-612.

111. Song SQ, Gan HL, Zhang JQ, Feng L, Sun JC, Wang SX. Postconditioning through lower limb ischemia-reperfusion can alleviate lung ischemia-reperfusion injury. Int J Clin Exp Med. 2015;8(9):14953-61.

112. Cao QF, Qu MJ, Yang WQ, Wang DP, Zhang MH, Di SB. Ischemia postconditioning preventing lung ischemia-reperfusion injury. Gene. 2015;554(1):120-4.

113. Jun N, Ke J, Gang C, Lin C, Jinsong L, Jianjun W. The protective effect of ischemic preconditioning associated with altered gene expression profiles in rat lung after reperfusion. J Surg Res. 2011;168(2):281-93.

114. Lin E, Snell GI, Levvey BJ, Mifsud N, Paul M, Buckland MR, Gooi J, Marasco S, Sharland AF, Myles PS. Safety, feasibility, and effect of remote ischemic conditioning in patients undergoing lung transplantation. J Heart Lung Transplant. 2014;33(11):1139-48.

115. Dembinski R, Brackhahn W, Henzler D, Rott A, Bensberg R, Kuhlen R, Rossaint R. Cardiopulmonary effects of iloprost in experimental acute lung injury. Eur Respir J. 2005;25(1):81-7.

116. Naka Y, Roy DK, Liao H, Chowdhury NC, Michler RE, Oz MC, Pinsky DJ. cAMP-mediated vascular protection in an orthotopic rat lung transplant model. Insights into the mechanism of action of prostaglandin E1 to improve lung preservation. Circ Res. 1996;79(4):773-83.

117. Klepetko W, Muller MR, Khunl-Brady G, Wisser W, Windisch A, Eckersberger F, Wolner E. Beneficial effect of iloprost on early pulmonary function after lung preservation with modified eurocollins solution. Thorac Cardiovasc Surg. 1989;37(3):174-9.

118. Jiang J, Chan A, Ali S, Saha A, Haushalter KJ, Lam WL, Glasheen M, Parker J, Brenner M, Mahon SB, Patel HH, Ambasudhan R, Lipton SA, Pilz RB, Boss GR. Hydrogen sulfide-mechanisms of toxicity and development of an antidote. Sci Rep. 2016;6:20831.

119. Dugbartey GJ, Bouma HR, Lobb I, Sener A. Hydrogen sulfide: a novel nephroprotectant against cisplatin-induced renal toxicity. Nitric Oxide. 2016;57:15-20.

120. Wallace JL, Wang R. Hydrogen sulfide-based therapeutics: exploiting a unique but ubiquitous gasotransmitter. Nat Rev Drug Discov. 2015;14(5):329-45.

121. Meng C, Cui X, Qi S, Zhang J, Kang J, Zhou H. Lung inflation with hydrogen sulfide during the warm ischemia phase ameliorates injury in rat donor lungs via metabolic inhibition after cardiac death. Surgery. 2017;161(5):1287-98.

122. Wu J, Wei J, You X, Chen X, Zhu H, Zhu X, Liu Y, Xu M. Inhibition of hydrogen sulfide generation contributes to lung injury after experimental orthotopic lung transplantation. J Surg Res. 2013;182(1):e25-33.

123. Fu Z, Liu X, Geng B, Fang L, Tang C. Hydrogen sulfide protects rat lung from ischemia-reperfusion injury. Life Sci. 2008;82(23-24):1196-202.

124. George TJ, Arnaoutakis GJ, Beaty CA, Jandu SK, Santhanam L, Berkowitz DE, Shah AS. Inhaled hydrogen sulfide improves graft function in an experimental model of lung transplantation. J Surg Res. 2012;178(2):593-600.

125. Huang CS, Kawamura T, Toyoda Y, Nakao A. Recent advances in hydrogen research as a therapeutic medical gas. Free Radic Res. 2010;44(9):971-82. 
126. Meng C, Ma L, Niu L, Cui X, Liu J, Kang J, Liu R, Xing J, Jiang $\mathrm{C}$, Zhou $\mathrm{H}$. Protection of donor lung inflation in the setting of cold ischemia against ischemia-reperfusion injury with carbon monoxide, hydrogen, or both in rats. Life Sci. 2016;151:199-206.

127. Ryter SW, Otterbein LE, Morse D, Choi AM. Heme oxygenase/ carbon monoxide signaling pathways: regulation and functional significance. Mol Cell Biochem. 2002;234-235(1-2):249-63.

128. Maicas N, van der Vlag J, Bublitz J, Florquin S, Bakker-van Bebber M, Dinarello CA, Verweij V, Masereeuw R, Joosten LA, Hilbrands LB. Human Alpha-1-Antitrypsin (hAAT) therapy reduces renal dysfunction and acute tubular necrosis in a murine model of bilateral kidney ischemia-reperfusion injury. PLoS ONE. 2017;12(2):e0168981.

129. Gotzfried J, Smirnova NF, Morrone C, Korkmaz B, Yildirim AO, Eickelberg O, Jenne DE. Preservation with alpha1-antitrypsin improves primary graft function of murine lung transplants. J Heart Lung Transplant. 2018;37(8):1021-8.

130. Iskender I, Sakamoto J, Nakajima D, Lin H, Chen M, Kim H, Guan Z, Del Sorbo L, Hwang D, Waddell TK, Cypel M, Keshavjee S, Liu M. Human alpha1-antitrypsin improves early post-transplant lung function: pre-clinical studies in a pig lung transplant model. J Heart Lung Transplant. 2016;35(7):913-21.

131. Lin H, Chen M, Tian F, Tikkanen J, Ding L, Andrew Cheung HY, Nakajima D, Wang Z, Mariscal A, Hwang D, Cypel M, Keshavjee S, Liu M. alpha1-Anti-trypsin improves function of porcine donor lungs during ex-vivo lung perfusion. J Heart Lung Transplant. 2018;37(5):656-66.

132. Hla T. Signaling and biological actions of sphingosine 1-phosphate. Pharmacol Res. 2003;47(5):401-7.

133. Sawicka E, Zuany-Amorim C, Manlius C, Trifilieff A, Brinkmann V, Kemeny DM, Walker C. Inhibition of Th1- and Th2mediated airway inflammation by the sphingosine 1-phosphate receptor agonist FTY720. J Immunol. 2003;171(11):6206-14.

134. Stone ML, Sharma AK, Zhao Y, Charles EJ, Huerter ME, Johnston WF, Kron IL, Lynch KR, Laubach VE. Sphingosine1-phosphate receptor 1 agonism attenuates lung ischemiareperfusion injury. Am J Physiol Lung Cell Mol Physiol. 2015;308(12):L1245-L12521252.

135. Okazaki M, Kreisel F, Richardson SB, Kreisel D, Krupnick AS, Patterson GA, Gelman AE. Sphingosine 1-phosphate inhibits ischemia reperfusion injury following experimental lung transplantation. Am J Transplant. 2007;7(4):751-8.

136. Mehaffey JH, Charles EJ, Narahari AK, Schubert S, Laubach VE, Teman NR, Lynch KR, Kron IL, Sharma AK. Increasing circulating sphingosine-1-phosphate attenuates lung injury during ex vivo lung perfusion. J Thorac Cardiovasc Surg. 2018;156(2):910-7.

137. Stone ML, Sharma AK, Mas VR, Gehrau RC, Mulloy DP, Zhao Y, Lau CL, Kron IL, Huerter ME, Laubach VE. Ex vivo perfusion with adenosine A2A receptor agonist enhances rehabilitation of murine donor lungs after circulatory death. Transplantation. 2015;99(12):2494-503.

138. Sharma AK, Laubach VE, Ramos SI, Zhao Y, Stukenborg G, Linden J, Kron IL, Yang Z. Adenosine A2A receptor activation on $\mathrm{CD} 4+\mathrm{T}$ lymphocytes and neutrophils attenuates lung ischemia-reperfusion injury. J Thorac Cardiovasc Surg. 2010;139(2):474-82.

139. Fernandez LG, Sharma AK, LaPar DJ, Kron IL, Laubach VE. Adenosine A1 receptor activation attenuates lung ischemia-reperfusion injury. J Thorac Cardiovasc Surg. 2013;145(6):1654-9.

140. Mulloy DP, Sharma AK, Fernandez LG, Zhao Y, Lau CL, Kron IL, Laubach VE. Adenosine A3 receptor activation attenuates lung ischemia-reperfusion injury. Ann Thorac Surg. 2013;95(5):1762-7.

141. Gazoni LM, Walters DM, Unger EB, Linden J, Kron IL, Laubach VE. Activation of A1, A2A, or A3 adenosine receptors attenuates lung ischemia-reperfusion injury. J Thorac Cardiovasc Surg. 2010;140(2):440-6.

142. Smail H, Baste JM, Gay A, Begueret H, Noel R, Morin JP, Litzler PY. Role of inflammatory cells and adenosine in lung ischemia reoxygenation injury using a model of lung donation after cardiac death. Exp Lung Res. 2016;42(3):131-41.

143. Wagner CE, Pope NH, Charles EJ, Huerter ME, Sharma AK, Salmon MD, Carter BT, Stoler MH, Lau CL, Laubach VE, Kron IL. Ex vivo lung perfusion with adenosine A2A receptor agonist allows prolonged cold preservation of lungs donated after cardiac death. J Thorac Cardiovasc Surg. 2016;151(2):538-45.

144. Del Sorbo L, Costamagna A, Muraca G, Rotondo G, Civiletti F, Vizio B, Bosco O, Martin Conte EL, Frati G, Delsedime L, Lupia E, Fanelli V, Ranieri VM. Intratracheal administration of small interfering RNA targeting fas reduces lung ischemia-reperfusion injury. Crit Care Med. 2016;44(8):e604-e613613.

145. Kim H, Zamel R, Bai XH, Lu C, Keshavjee S, Liu M. Ischemiareperfusion induces death receptor-independent necroptosis via calpain-STAT3 activation in a lung transplant setting. Am J Physiol Lung Cell Mol Physiol. 2018;315(4):L595-1608.

146. Zhao H, Ning J, Lemaire A, Koumpa FS, Sun JJ, Fung A, Gu J, Yi B, Lu K, Ma D. Necroptosis and parthanatos are involved in remote lung injury after receiving ischemic renal allografts in rats. Kidney Int. 2015;87(4):738-48.

147. Abecassis A, Schuster R, Shahaf G, Ozeri E, Green R, Ochayon DE, Rider P, Lewis EC. alpha1-antitrypsin increases interleukin-1 receptor antagonist production during pancreatic islet graft transplantation. Cell Mol Immunol. 2014;11(4):377-86.

Publisher's Note Springer Nature remains neutral with regard to jurisdictional claims in published maps and institutional affiliations. 